\title{
居住体験と住環境の理想像の類型 \\ 一地域差と志向性に関する基礎的考察一 \\ THE LIVING EXPERIENCE AND THE IMAGE OF THE IDEAL DWELLING ENVIRONMENT
}

\author{
周 静 敏*, 服 部 岑 生**, 真境名 達哉* \\ Jingmin ZHOU, Mineki HATTORI and Tatsuya MAJIKINA
}

\begin{abstract}
In contemporary city, although some traditional dwellings exist,most of the dwelling environments are created in modern way by urban designers and architects.However, are the residents satisfied with these? What living experiences have they gotten in their lives? Do they agree at that the new is better than the traditional? What are their ideal dwelling environment and what factors form that ideal image? We will search for these in this paper.
\end{abstract}

Keywords: proto-landscape,living environment,image of ideal environment,living experience 原風景、住環境、理想的環境イメージ、居住体験

\section{1.はじめに}

現代の都市の住環境は、歴史的な部分を残しているが 多くは近代的な集合住宅と都市計画の観点にたって形成 されてきたものである。この住環境は、過去の伝統的な 住環境と比㜞して果たして理想的なものであるかどう か。現代の人間は、どのように評価しているのか、理想 的な住環境とはどのようなイメージのものであり、それ らはどのような要因によって理想とされているのか。本 研究は、これらの関心について、現代の都市居住者にヒ ヤリングを行い、この研究の第一段階として、概略的な 知見を得ることを目的としている。

\section{2.住環境の理想についての既往の理論}

環境や住宅の理想については、すでに類似の関心を基 に先駆的な研究や検討がなされている。住環境に関する 理想については、先ず扇田信参1) が住宅の理想を「住に
関する不満や要求を生み出す潜在的な基盤となる意識が 住意識である・・住意識をもとにして・..言葉や意

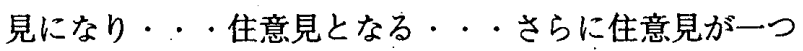
の体系だった意見として組み立てられ住宅に对するまと まったイメージを描きだそうとしている場合、それを住 宅理想とよふ。」と説明している。この考え方は、住宅 に限っているが、住宅を含む環境に範囲を広げても常識 的に考えて問題はない。「理想」が体系性をもっている としている点に特徵がある。例えば、住環境についての 単純な欲求や要求などは、意見であり、理想のレベルに 達しないということになる。住宅計画の既往研究におい て、扇田信以降は理想が概念的に検討された経䋨はない。

住環境の理想像に関係する研究として、原風景の研究 がある。原風景の概念は、その初期の戦後の議論では、 奥野健男参2)のように「筫しさ、つらさや豊かでない生 活面など」の消極的な側面から考えることが多かった。 しかし、「原風景」には、肯定的・積極的な面、つまり
*千葉大学自然科学研究科 博士課程.工修

** 千葉大学工学部建築学科 教授. 工博
Graduate Student, Chiba Univ., M. Eng.

Prof., Dept. of Architecture, Faculty of Engineering, Chiba Univ., Dr. Eng. 
豊かで、快適で、理想的な将来に対する憧れが内包され ている。そのような観点の原風景論が、最近の延藤安弘 などの議論に現れてきている。

70年代初期、小山田善次郎参3) は、「都市景観を構成 する諸要素に関して一般の人々がどのようなイメージを 抱くかということを明らかにする」研究を行って、都市の 生活環境を美しく快適に保つための諸問題を検討した。 この論文はまだ原風景という言葉が使われていなかっ た。近年では、西村匡達ら参4) は、「都市の心象風景の 形成・想起要因に関する研究」を行い、さらに、「名古屋 市の心象風景の場所性について」の研究を行った。そのほ か、茂原朋子ら参5）は、「原風景」を“自己形成期に体験 したものの中で、現在においてもある感情の想起をとも なって繰り返し想いおこされる風景あるいは情景”と定 義し、「青年の “原風景” の特性と構造に関する研究」を 行った。1987年に、延藤安弘参6) は、大阪（千里二ュー タウン）に住む九州出身者の住まいをめぐる原風景の調 査によって「住志向に関わる原風景一ふるさとの思い出か らみた住居の計画」の研究を行った。延藤安弘の原風景に 対する解釈は、人々の“こころに染く刻みこまれた風景 であって、その多くは、ふるさとにおける幼年の日々に 経験した忘れがたい風物の、あるとき、あるところの思 い出に属する、こころの風景のこと”としている。延藤 安弘は、子供自身の環境への参与の違いによって、原風 景の型を「自律的原風景」と「他律的原風景」の2つに分け ている。このように、子供の環境への参与と受動的影響 という軸で、原風景の型を区分することは、一つの切り 口であるが、両者の中間に存在する型もあまりに多く、 原風景の型の中軸にするにはあいまいさがあると考えら れる。これらの研究のおおくは原風景を、風景という点 に絞った一面的なアプローチから始めている。結局、今 までの「原風景」の研究では、その「風景」に関する特性を 主に論じたものが多かった。しかしながら、人間はある 風景に視覚的に反応するとき、その風景の自然的な面を 評価するだけではなく、その周辺の環境や生活空間に对 する認識などを含めて考えないだろうか。本研究は、こ れまでの「原風景」の概念から「原環境」(風景だけでな く、環境或いは空間を含むもの）という概念に広げ、「原風 景」を含む環境一「原環境」を明らかにすることとした。

原風景に関する論議で、岩田慶治参8) は原風景には、 「原とという言葉がドイッ語urーにあたるのかそれとも protoーにあたるか、解釈がわかれる」として、唯一の本源 的な風量と複数ある類型としての風景の二つの意味があ ることを指摘した。これは、風景の理想として原風景を 単純に意味づける考え方に問題があることを示唆してい る。しかし、本源的な風景というものがあるとすると、 例えば日本人にとっての本源的な風景というようなもの であるが、関根康正参7）が示すように時代の変化による 原風景の相対的な変化が報告されており、原風景は体験 の多様性とともにur-が変質し複数のproto-風景型になって いっているのではないだろうか。本研究では住環境につ いての体験と理想を明らかにすることを目的としている が、本源的なものを見いだそうとするのか、その類型を明 らかにするかは、同様に問題となるが、proto-環境という意 昧で、類型的な住環境像を明らかにしたいと考えた。

延藤安弘は、個人の原風景のあり方からその人の住志 向一住に関する理想あるいは理想に類する意識一を見い だそうとしている。延藤安弘は、原風景を個人の体験に 根ざした感動のある風景の記憶としており、その調査か ら住宅計画の手がかりを見いだすことで、従来にない理 想的な住宅計画が可能であると考えている。原風景が個 人の理想性を内在するという考え方は、原風景に関す る、本研究と深く関わる意味を明らかにしている。原風 景を調査する際に、感動の体験を基礎にすることが、調 査された原風詈に理想性を内在させることになると推理 できる。同様の考え方に立つならば、本研究でも、住環 境計画における有効性を確保するためには、単なる体験 としての住環境ではなくて、理想としての体験を問うこ とが重要になる。

原風景から環境へ視点を移していくと、「ふるさと」の 概念との関連に気づく。日本ではふるさとの研究は、特 に住環境の研究分野では、延藤安弘や茂原朋子らの原風 景の研究の中で語られており、すでに見た問題以外の提 起はみられない。外国ではF.Lレンッローマイス参9)の 体系的な考察による文献がある。この中で、H.トライネ ンのふるさとの定義「場所への象徵的な愛着」が紹介され ており、その愛着が空間的なものというより人間的な交 流の記憶によることが強調されている。この考え方は、 多くの社会学者の支持を得ているという。しかしながら、 今回の研究では、住環境の理想を人間の交流を含む観点 までは広げない。

\section{3.研究方法}

調查方法としては、サンプル写真（図-1a,b）によるイ メージの呈示と配置やデザインなどの簡単な説明（表 1,2）により、街頭インタビューを行った。

表-1 居住体験の種類注1)

\begin{tabular}{|c|c|c|c|c|c|c|}
\hline \multirow{2}{*}{\multicolumn{2}{|c|}{ タイプ 特街 }} & \multirow{2}{*}{$\begin{array}{l}\text { 住棟 } \\
\text { の形 }\end{array}$} & \multirow{2}{*}{$\begin{array}{l}\text { 配 } \\
\text { 霊 }\end{array}$} & \multirow{2}{*}{$\begin{array}{l}\text { 材料· } \\
\text { デザイン }\end{array}$} & \multicolumn{2}{|c|}{ 瑵境 } \\
\hline & & & & & 緑の置 & 立 地 \\
\hline \multirow{3}{*}{$\begin{array}{l}\text { 自 } \\
\text { 然 } \\
\text { 系 }\end{array}$} & 山村 & 戸建 & 分散 & 营釷きと木造 & 多W & 山間部 \\
\hline & 海村 & 戸建 & 分散 & 木造 & 多い & 海边 \\
\hline & 川村 & 豆建 & 沿道 & 木造 & 普通 & 川沿 \\
\hline \multirow{3}{*}{$\begin{array}{l}\text { 村 } \\
\text { 落 } \\
\text { 系 }\end{array}$} & 奮村 & 戸建 & 浩道 & 木造 & 少ない & 街道沿 \\
\hline & 農村「旧」 & 戸建 & 沿道 & 萁革きと木造 & 多W & 屡村部 \\
\hline & 農村「新」 & 戸建 & 泾道 & 木造 & 普通 & 㤟村部 \\
\hline \multirow{4}{*}{$\begin{array}{l}\text { 都 } \\
\text { 市 } \\
\text { 系 }\end{array}$} & 下町の長屋 & 2 層建続 & 沿道 & 木造 & 少ない & 下町 \\
\hline & 䓃建て住宅 & 戸建 & 沿道 & 木造 & 少ない & 郊外 \\
\hline & 団地住宅 & 中層板状 & 平行 & コンクリート & 少ない & 郊外 \\
\hline & マンション & 中層板状 & 複合 & コンクリート & 少ない & 市街地 \\
\hline
\end{tabular}




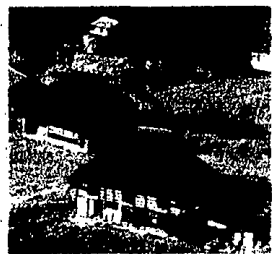

山村

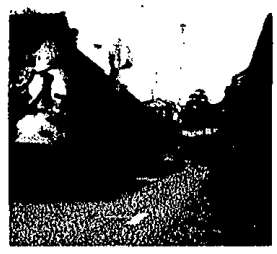

. 農村「新」

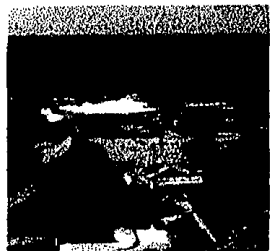

海村

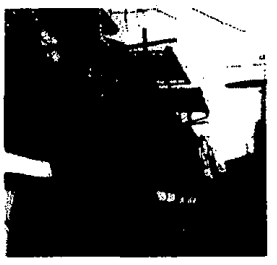

下町の長屋

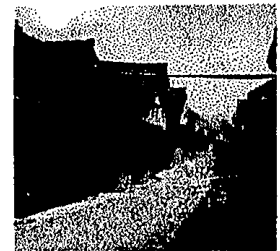

川村

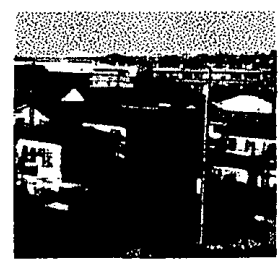

戸建て住宅

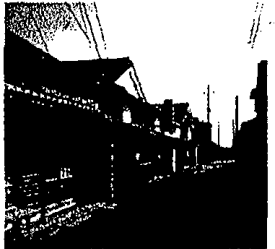

街村

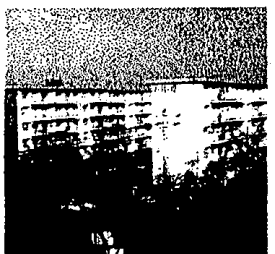

団地住宅

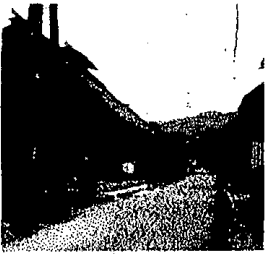

農村「旧」

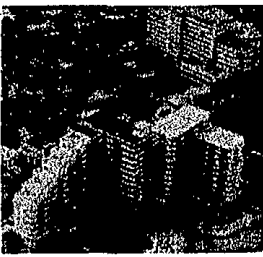

マンション

図-1a 居住体験の写真サンプル

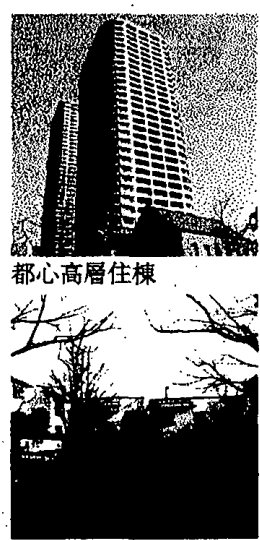

囲み低層住棟

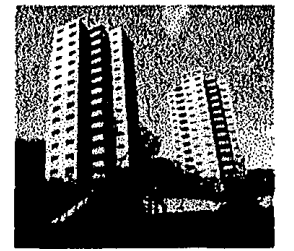

郊外高層住棟

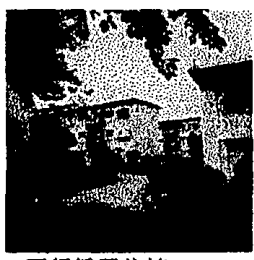

平行低層住棟
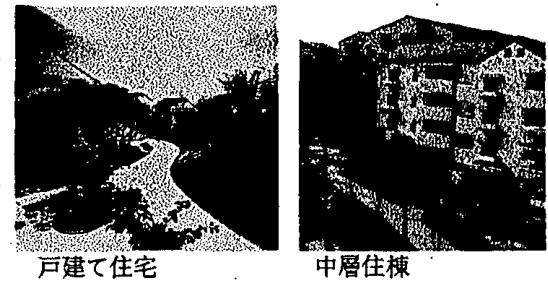

中層住梗

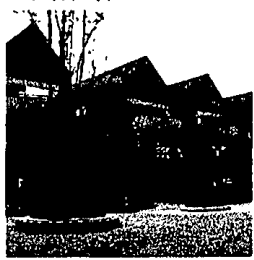

地上バーキンク式中㕣住棟・中庭式新デサイン住棟 ストリート式新デサイン住棟

図-1 b 理想像の写真サンプル

居住体験については、表・1のように、自然系、村落 系、都市系の三つの環境を前提に、古さの順でよく見ら れる住環境を選んだ。具体的には、10種類で、「山村」、 「海村」、「川村」を自然系のグループとし、「街村」、「農 村(旧)」、「農村(新)」を村落系のグループとし、「下町の長 屋」「「建て住宅」「団地住宅」、「マンション」を都市 系のグループとした。

近年では、都市と郊外にいろいろな新しい住環境がで き、タイプとしても豊かである。そこで、理想像（表. 2）については、建物の階層、デザインの特徵等の条件 によって、9種類に分け、「平行低層住棟」「囲み低層住 棟」「戸建住宅」の3つを低層系のグループ、「中層住棟」、 「地上パーキング式中層住棟」の2つを中層系のグループ、 「都市高層住棟」「郊外高層住棟」の2つを高層系のグルー
表-2 理想像の種類注 2 )

\begin{tabular}{|c|c|c|c|c|c|c|}
\hline \multirow{2}{*}{\multicolumn{2}{|c|}{ タイブ 特徵 }} & \multirow{2}{*}{$\begin{array}{l}\text { 住棟 } \\
\text { の形 } \\
\end{array}$} & \multirow{2}{*}{ 配 } & \multirow{2}{*}{$\begin{array}{l}\vec{F} サ \\
\text { イン } \\
\end{array}$} & \multicolumn{2}{|c|}{ 理境 } \\
\hline & & & & & 娽の量 & 立 \\
\hline \multirow{2}{*}{$\begin{array}{l}\text { 高 } \\
\text { 層 } \\
\text { 系 }\end{array}$} & 都心高層住棟 & 高層塔状 & 分散 & - & 少ない & 市街地 \\
\hline & 郊外高 & 状 & 分散 & & 多い & 郊外 \\
\hline \multirow{3}{*}{$\begin{array}{l}\text { 低 } \\
\text { 層 } \\
\text { 系。 }\end{array}$} & & 層板状 & 平行 & & 多い & 郊外 \\
\hline & 囲み任 & 2 層連続 & ロの字 & & 多w & 郊外 \\
\hline & 戸建 & 戸建 & 沿道 & & 多い & 郊外 \\
\hline \multirow{2}{*}{$\begin{array}{l}\text { 中 } \\
\text { 層 } \\
\text { 系 }\end{array}$} & 中層住楝 & 中層板状 & 平行 & & 普通 & 郊外 \\
\hline & $\begin{array}{l}\text { 地上バーキン } \\
\text { 中 層 住 }\end{array}$ & 掘板状 & 平行 & & 少ない & 郊外 \\
\hline 新 & $\begin{array}{l}\text { 中涎式新宁サ } \\
\text { 住 }\end{array}$ & 中層板状 & 中庭 & 新 & 多い & 郊外 \\
\hline * & 新デザイン住 & 中層板状 & 沿道 & *NI & 普通 & 郊外 \\
\hline
\end{tabular}

プ、「中庭式新デザイン住棟」、ストリート式新デザイン 住棟」を新デザイン系のグループとした。

調査地域としては、ニュータウンである多摩（多摩セ ンター駅前）、郊外都市の千葉（パルコ前広場）、田舎 の伝統的な古い町である静岡県松崎町（銀座通り）を選 定した。そして、一般的な通行人を対象として選び、男女 及び老若の割合、有無職者の割合などについては、1対 1、合計 100 人ずつを目途に調查した（表-3）。

表-3 地域別調査人数注3)

\begin{tabular}{|c|c|c|c|}
\hline 觡查対象 & \multicolumn{2}{|c|}{ 一般の通行人 } & 시 \\
\hline 調查地域 & 千葉 & 多摩 & $\begin{array}{l}\text { 松崎 } \\
\end{array}$ \\
\hline 男女比 男/女! & $48 / 52$ & $46 / 64$ & $18 / 52$ \\
\hline 老若比 [老/若] & $55 / 45$ & $58 / 62$ & $32 / 38$ \\
\hline 戰亲の有無 & $62 / 38$ & $35 / 75$ & $30 / 40$ \\
\hline 居住者/非居住者 & $69 / 31$ & $73 / 37$ & $70 / 0$ \\
\hline 酷查人数 & 100 & 110 & 70 \\
\hline 合竐 & & 280 & \\
\hline
\end{tabular}


表-4 調查者用の調査シート

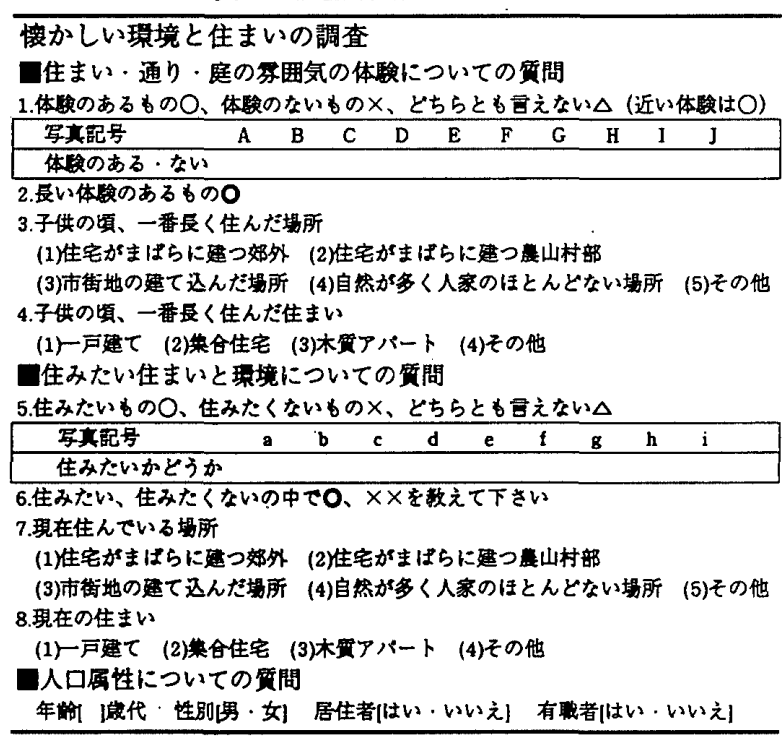

調查の内容は、居住体験や理想像のSD法による評価と 人口的な属性などについてインタビューした。居住体験 は（、、、、、×の4段階評価とした。質問 $1 、 2$ (表-4 参照）について、まず質問1で、○（有り）と×（な

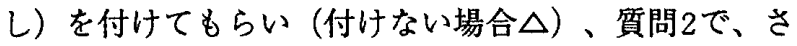
らに長い体験のあるものを○として回答させた。理想像

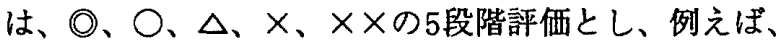
ます質問 5 と6について、質問5で、○（理想的）と $\times$ （理想的でない）を付けてもらい（付けない場合 $\Delta ） 、$ 質問6で、さらに、もっと好むもの、より嫌いものをそ れぞれ○と××として回答させた（表-4）。

\section{4.基礎的な結果}

(1)調查対象別の居住体験の特性

調查地域別に回答（表-4質問1,2の合成）の各項目の平 均値を算出し、イメージプロフィール注4)を得た。居住体 験について、「体験したことがない」から長く体験した」

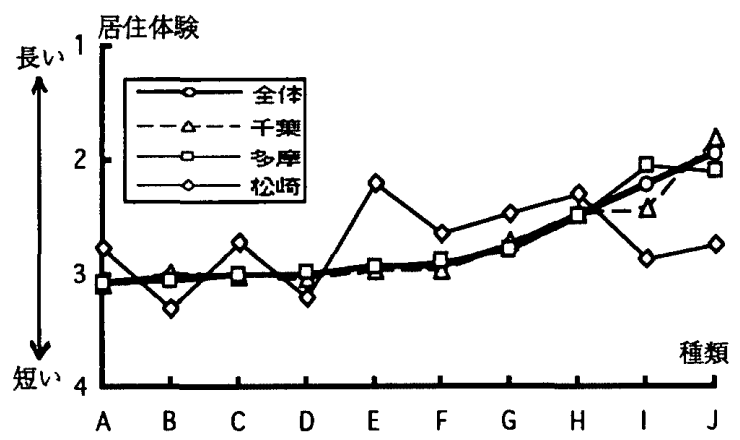

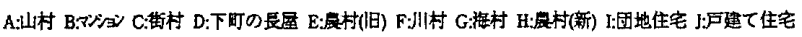
図·2 居住体験のイメージプロフィール
の平均値をY軸に取り、平均の大きいものから順に $\mathrm{X}$ 軸に 左から右の順にプロットした（図-2）。

全体(千葉と多摩、以下同様)と千葉及び多摩の傾向 は、ほほ同じである。多摩は「団地住宅」と「戸建て住宅」 で、一部傾向が異なっている。

松崎の傾向は、全体の平均と大きく異なっている。農 村(旧)の体験が長く、団地や戸建て住宅の体験が短く出 ている。

(2)調查対象別の理想像の特性

理想像(質問 5,6 )注5)について「住みたい」イメージの評 価の平均值を $\mathrm{Y}$ 軸に取り、平均順に $\mathrm{X}$ 軸の左から右の 順にプロットした（図-3）。

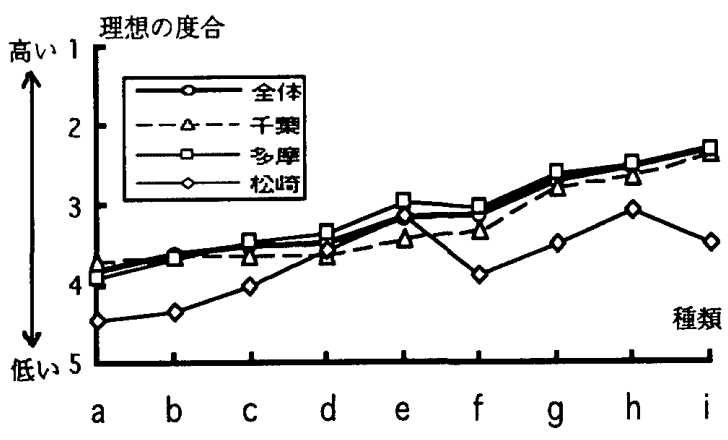

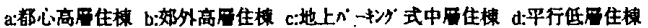

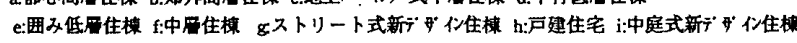
図-3 理想像のイメージプロフィール

全体と千葉と多摩の傾向は、ほほ同じであった。

細かく見ると、千葉と多摩は「中庭式新デザイン住棟」 と「郊外高層住棟」に対しての評価は全く同じだが、評価 の平均値が中くらいの「曲み低層住棟」などでは、多摩は 千葉より理想的という結果が出た。

松崎の結果を見ると、平均值がやや高く、「囲み低層住 棟」と「平行低層住棟」が割りと好まれ、千葉と多摩で人気 がある「中庭式新デザイン住棟」はあまり気に入られな かった。

5.居住体験と理想像の類型 (表-5,表-6)

ヒヤリングの回答（表-4の項目1と5）をデータに、 ウォード法 (minimum variance) のクラスター分析に よって、全体、千葉、多摩、松崎毎に、居住体験と理想 像のそれぞれに複数のタイプからなるグループを得た。 各グループ毎のイメージプロフィールを比べ、平均得点 の低いグループ(理想的あるいは体験が長い)から順に配 列し、命名した。

以下表-5、6の説明について、「理想的」あるいは「長体 験」から「非理想的」あるいは「無体験」までの平均得点を記 号化し、1.00-2.00の範囲を○の記号で「非常に高い」を示 


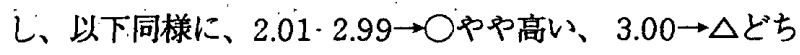
らともいえない、3.01-3.99 $\rightarrow$ Xpp低い、4.00-5.00 $\rightarrow \times \times$ 非常に低いを示した。

(1)居住体験のクラスター分析 (表-5)

表-5 居住体験のクラスタ一分析の結果

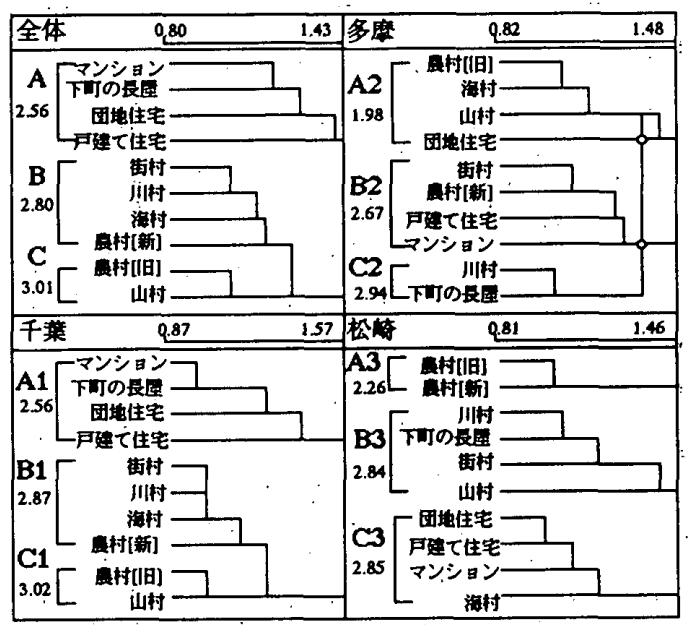

( $\mathrm{A}, \mathrm{B}, \mathrm{C}$ の厂の数値は、体験の程度の平均得点)

全体については、主に[A](O)、[B]!O)、及び必ずしも体 験が長くない $[C](X)$ のつのグループが得られた。 $[\mathrm{A}]$ は、マンション、下町の長屋、団地住宅、戸建て住宅な どの体験で、現代的な都市によく見られる環境である。 $[B]$ 、多様な伝統的古い村落で、[C]は、山の周辺の街村 の環境である。

千葉については、 $[\mathrm{A} 11$ 、 $\mid \mathrm{B} 1$ 1、 $|\mathrm{C} 1|$ 淂られ、各グルー プの構成は全体の結果と同じく、平均得点もほほ同様で あった。

多摩については、[A2](О)、[B2/(○)、[C2](О)の3つの グループが得られ、いずれのグループも体験が長い。特 に体験の長い[A2]は、自然が多い山や海などの周辺の村 落と団地住宅である点に特徵がある。[B2]は、全体の[A] と近いが、「下町の長屋」と「団地」に替わり、より古い「街 村」と「農村」が選ばれて、やや伝統的な都市あるいは都市 と郊外の境界の周辺での体験㑯向が現われている。[C2] は、郊外の川村と都市の下町の長屋で構成されている。

松崎にういては、[A3](O)、[B3](O)、[C3](O)の3つの グループが得られた。[A3]は、松崎町のような山の周辺 の環境により構成され、此較的長く体験したことを示し ている。[B3]は、様々な古い伝統的な街村により構成さ れ、[C3]の構成は、全体の[A]と似ているが、「下町の長 屋」が「海村」に替わり、松畸の地理環境の特徵を反映して いると考えられる。

千葉、多摩、松畸に共通の体験の長さを比べると、都 市系の居住体験の順位は千葉 $\rightarrow$ 多摩 $\rightarrow$ 松畸であり、村落 亲の体験順位は、松猗 $\rightarrow$ 葉 $\rightarrow$ 多摩であった。自然系の 体験は多摩が千葉より長かった。
この結果をみると、千葉は、都市の居住体験の長い人 が多く、農漁村部の居住体験が全体として少くなってお り、都市の居住体験がある流入人口が多い地域であるこ とを示している。その一方、多摩ニュータウンは、同様 に流入人口で構成されるが、比較的新しい人口であるこ とからか、その居住体験は割と豊かで、農村部の居住体 験のある人も多く見られる。松崎は、山や海で囲まれて いる伝統的な町で、故郷から離れたことがない人が多数 であるため、伝統的な町しか体験してない人が多いと考 えられる。

(2)理想像のクラスター分析 (表-6)

表-6 理想像のクラスター分析の結果

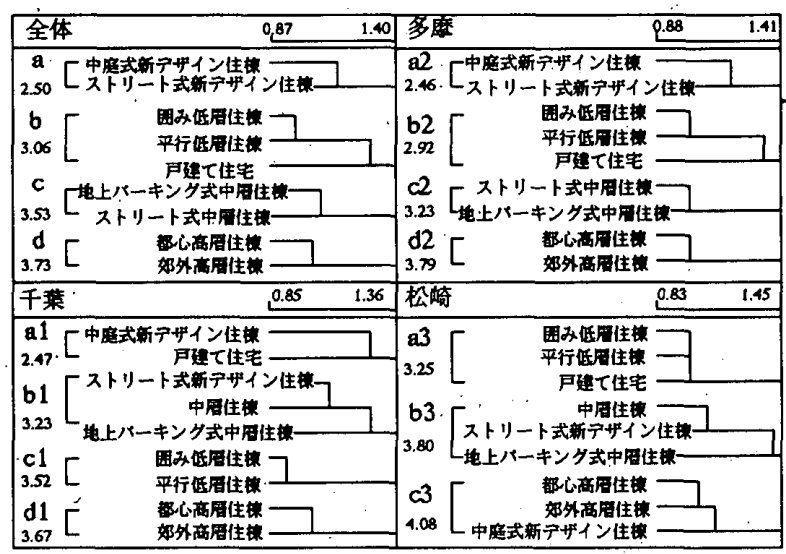

(a,b,cの下の数值は、理想の程度の平均得点)

全体については、 $[a](O) 、[b](X) 、[c](X) 、[d](X) の 4 つ$ のグループが得られ、平均值がろより低い理想的なイ メージは[a]のみであった。|a|は、建物のデザインが新しい ものにより構成され、[b]は、緑が多い低層住宅により構 成され、[c]は、中層住棟により構成されている。[d]は、 高層住棟の特徽を持っていると見られている。

千葉については、[a1](O)、 $[\mathrm{b} 1](\times) 、[\mathrm{c} 1](\times) 、[\mathrm{~d} 1](\times)$

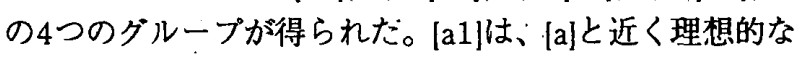
唯一のグループである。[b1]は、[c]の特徴に近いが、「ス トリート式新デザイン住棟」が入っている。[c1]と[d1]につ いては、全体の[b]と[d]の特徽とほどんと同様であった。

多摩については、[a2] $(\bigcirc) 、[\mathrm{~b} 2](\bigcirc) 、[\mathrm{c} 2](\times) 、[\mathrm{~d} 2](\times)$, の4つのグループが得られ、全体と一致している。しか し、 [b2]は理想的なグループとなり、他の地域と異な り、囲み型や低層の集合住宅が肯定的に見られているこ とに特徵がある。

松畸については、[a 3$](\times) 、[b 3](\times) と[\mathrm{c} 3](\times \times)$ が得ら れ、[a3]は、全体の[b]のように低層住棟で構成されてい るが、最も理想的となっていない。[b3]は千葉の[b1]と同 じく、新しいデザインの特性がやや注目されている。[c3] は、高層住棟について、他地域の高層系と一致してお り、「中庭式新デザイン住棟」も入っている。 
以上の結果をみると、千葉と多摩は、建物のデザイン 性や高層住棟に对しての認識がかなり一致しているが、 低層住棟と中層住棟に対しての評価は逆になった。これ は、多摩ニュータウンに拈ける新しいデザインや中庭式 の住宅が評価されているのではないだろうか。ここに は、多摩の回答者の体験と評価が出ており、他地区の回 答者は一般的なイメージでしか判断できなかったといえ るかもしれない。しかし、全体の中で、新しいデザイン のグループは、一番上位に入っており、多摩のみなら ず、他の地区からも少なからず支持が出ていると予想さ れる。

松畸の新しい住環境に対しての反応はかなり消極的、 特にデザインを理想とする意識は見られなかった。これ は、千葉と多摩は近代的で、人々は単に住むことを求め るだけでなく、より一層個性がある美しいデザインの住 環境を追求しているわけである。松崎は田舎の伝統的な 町で、伝統的、自然的な環境のまま育ってきた人々が多 く、故郷に対する愛着が根強く、反近代的な傾向が強い ということがその消極的な反応の原因の一つと思われ る。

(3)居住体験と理想像の両者の関連 （表-7,表-8）

居住体験と理想像の両者の関連を探るため、各々の調 查時に設定した種類への回答に基づき、回答者をそれぞ れ以下に説明する8タイプ、16タイプに分類した。この タイプは、クラスター分析のグループが、イメージのグ ループとすると、同一体験、同一理想を持つ回答者の夕 イプである注6)。居住体験と理想像の類型について、独立 性の検定を行ったところ、差異が認められたので、それ ぞれの関係について分析を行った注71。

表-7 居住体験に関する回答者のタイプ注7)

\begin{tabular}{|c|c|c|c|c|c|c|c|c|}
\hline タイフ & Im & III & V & VII & WIn & 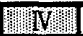 & $\overline{\mathrm{VI}}$ & VIII \\
\hline 特 & 自然 & 非自然 & 自然 & 韭自然 & 自然 & 非自然 & 自然 & 非自然 \\
\hline & & 落 & & 时落 & & 落 & & \\
\hline 徽 & \multicolumn{4}{|c|}{ 都市 } & \multicolumn{4}{|c|}{ 非都市 } \\
\hline
\end{tabular}

居住体験について、主に| I || II || IN]の3タイプの回答と なった。この3タイプの各特徴は、以下である。

[I ] (47.6\%)-一自然系・村落系・都市系了一全ての体験のある者 [II](28.6\%)一自然系・村落系・非都市系卜都市体験ない者 [IV] (16.2\%)一非自然系・村落系・非都市系] $\rightarrow$ 村落のみ体験の ある者
以上の3タイプは、共に村落系を体験している。さら に都市系対非都市系の体験比率はほほ1:1であった。これ からみると、日本の都市の居住者は農村の体験が共通し ていると考えられる。これは、日本の都市化が農村から 発展し、自然を少なくして、人口や建物の密度を序々に 高め、近代化を進めて行くシステムであり、農上都市化 注8)といわれるわけである。

そして、3タイプの内、|I]と[II]の自然系が81.1\%を占 めるのは、村落が多く見られる中の都市化の時期の居住 体験の状況を映したと思われる。例えば、千葉は、農上 都市化によりできた都市で、現在、自然が少なくなっ た。従って、この現象は、都市化に伴うもので、若者は 自然体験が少ないかもしれないが年笴りは体験があるは ずだと思われる。多摩は千葉と違い、人工的に造られた 特別のニュータウンであるから、自然が都会地より計画 的に残されている。

理想像について、以下の7つが主な回答のタイプとし て見出され、全体の $80.6 \%$ を占めた（先頭番号は表-8に 内容を示した）。

[15](22.4\%)一[非新デザイン系・低層・非高層・非中層] 低層のみが好きな者

[16](16.2\%)-非新デザイン系・非低層・非高層・非中層] ○どれも好まない者

[7](14.3\%)一新デザイン系・低層・非高層・非中層] $\rightarrow$ 新 しいデザインと低層を好む者

[5](8.6\%)一|新デザイン系・低層・非高層・中層 $\} \rightarrow$ 高層の みを嫌う者

[13](6.7\%)-[非新デザイン系・低層・非高層・中層] $\rightarrow$ 低層 と中層を好み、高層と新しいデザインを嫌う者

[8](6.2\%)一新デザイン系・非低層・非高層・非中層] 新 しいデザインのみを好む者

[1] $(6.2 \%)$-新デザイン系・低層・高層・中層小全てを好む者 7つタイプの特徵をまとめると、非高層系対高層系の 割合は $92.8 \%: 7.2 \%$ 、低層系対非低層系のは $72.2 \%$ : $27.8 \%$ 、非中層系対中層系のは $73.3 \%: 26.7 \%$ 、非新デザ イン系対新デザイン系のは $56.2 \%: 43.8 \%$ であるという結 果が得られた。ここから、高層好きな者は、極めて少な く、低層や中層系を好む者は、かなり多く、新デザイン 系を好む者はかなりいるが、非新デザイン系の傾向に比 べればやや弱いと見られる。

こうして、現代の人々は、新デザイン系についての見 方が違う人がいるが、住棟の高さに対する関心がより高

表-8＼cjkstart理想像に関する回答者のタイプ注7)

\begin{tabular}{|c|c|c|c|c|c|c|c|c|c|c|c|c|c|c|c|c|}
\hline タイフ & 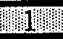 & 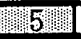 & 2 & 6 & 3 & 7 & 4 & 8) & 9 & III) & 10 & 14 & 11 & 15 & 12 & $16:$ \\
\hline \multirow{4}{*}{$\begin{array}{l}\text { 特 } \\
\text { 徽 }\end{array}$} & 高酋 & 非高用 & 高層 & 非高層 & 高原 & 非高周 & 高局 & 非高网 & 高層 & 非高層 & 高層 & 非高層 & 高厤 & 非高局 & 高局 & 非高廉 \\
\hline & \multicolumn{2}{|c|}{ 低層 } & \multicolumn{2}{|c|}{ 非低屋 } & \multicolumn{2}{|c|}{ 低展 } & \multicolumn{2}{|c|}{ 非低展 } & \multicolumn{2}{|c|}{ 低展 } & \multicolumn{2}{|c|}{ 非低層 } & & 欘 & \multicolumn{2}{|c|}{ 非低眉 } \\
\hline & \multicolumn{4}{|c|}{ 中層 } & \multicolumn{4}{|c|}{ 非中厝 } & \multicolumn{4}{|c|}{ 中層 } & \multicolumn{4}{|c|}{ 非中層 } \\
\hline & \multicolumn{8}{|c|}{ 新デザイン } & \multicolumn{8}{|c|}{ 非新デザイン } \\
\hline
\end{tabular}


く、高層嫌いで、低中層好きという意見でかなり一致し ている。

次に、居住体験と理想像の関連分析を行う（表9）。

タイプ[15]と[7]は、いずれも低層が好きだが、新デザ イン系に対して態度が異なっている。タイプ[15]は、[I] の体験者が最も多く、ついで、[N]の村落のみ体験ある者 が含まれている。つまり、都市、村落、自然のすべてに 体験のある者は、低層住棟を好み、新デザイン系に対す る関心は、ややうすいと考えられる。一方、低層も新デ ザイン系も好きなタイプ[7]は、[II]のように村落と自然 体験があり、都市体験のない者が多かった。

この結果から考えると、都市体験のある者は何よりも 低層住棟を期待している。これに対して、都市体験のな い者は、落ち着くような低層の住居を好んでいると共 に、より個性的で新しいデザインの住宅も望んでいるこ とが分かる。

[5]は、新デザイン系を好み、[13]は、新デザイン系を 嫌うが、いずれも低層と中層を好み、高層を嫌うタイプ であった。[5]の支持者は[Ijの上うなすべての体験のあ る者であり、[13]の支持者は、[II]のように村落や自然系 を体験していない者が多い。

ここに、すべての体験のある者においては、「低層しか 好まない者が新デザイン系を嫌い小、低層だけではなく 中層も好きな者が新デザイン系に好感も持っている」こと が分かる。

そして、[8]は、新デザイン系のみ好きなタイプであ ク、[16]は、どれも好きではない夕イプであった。居住 体験タイプについて、両方とも、 [ I || II ||IV]の順に多い が、理想と体験との間には特別な関倸が考えられない。

最後に、すべてを好きなタイプ[1]の結果を述べる。[1] は、7つのタイプの内、唯一の高層系を好むであった。 このタイプを選んだ人は、幾分们の村落系のみの者に多 い。これから、体験が村落亲に限られると住宅の高さや 形式について、強い好奇心が出ると推理されるが、必ず しも明確ではない。

(4)理想像の要因

\section{৩最も長い居住体験}

長い居住体験のある環境の上位3つは、「団地住宅」「戸 建て住宅」「農村(新)」である。これらの体験を持つほとん どの人は、低層に最も憧れ、新デザイン系と中層系に好 感を持つという点がほほ同様であった。「農村(新)」を長く

表·9 理想像と居住体験注9)

\begin{tabular}{|c|c|c|c|c|c|c|}
\hline \multirow{2}{*}{$\begin{array}{lll}\text { 理 } & \text { 想 } \\
& \alpha \\
\end{array}$} & \multicolumn{3}{|c|}{ 居住体頡タイフ } & \multicolumn{3}{|c|}{ 長い居住体験 } \\
\hline & & & IV & 里秋住电 & 往㘪 & 树新〉 \\
\hline & 5 & 4 & 179 & 6 & 5 & 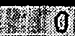 \\
\hline 新デザイン系 & 30 & 33 & 30 & 27 & 30 & 31 \\
\hline 佂層系 & 51 & 46 & 39 & 45 & $\overline{47}$ & 47 \\
\hline 中雷系 & 15 & 1 & 23 & 23 & $\overline{18}$ & 22 \\
\hline 合計(人) & 111 & 80 & $\overline{44}$ & 89 & 78 & 32 \\
\hline
\end{tabular}

体験する人は、他と比べ高層系をより嫌うという現象が 見られた（表-9右）。しかし、「農村(新)」しか体験して いない人(IN)は、高層系好きの傾向がより強かった（表9左)。

○幼年期の住環境と現在の居住環境

幼年期に、「市街地」と「農村」の両方を体験した人を比 べると、「市街地」は低層系、「農村」の方が中高層系を理 想とする項向が見られた（表-10左）。

幼年期の住まいは、ほとんどの人は「一戸建て」である が (資料省略)、現在の住まいは、「一戸建て」と「集合住 宅」となり、住まいが变化しつつあることを示している。 現在一戸建てに住む人は低層を好み、集合住宅に住む人 の方が中層系を好んでいる（表-10右）。

表·10 理想像と幼年期の住環境・現住まい注9)

\begin{tabular}{|c|c|c|c|c|}
\hline \multirow{2}{*}{$\begin{array}{lll} & \text { 想 } \\
& \text { \% } \\
\end{array}$} & \multicolumn{2}{|c|}{ 纤年期の住㯰境 } & \multicolumn{2}{|c|}{ 現住まい } \\
\hline & 市衙地 & 晨村 & & 集合住宅 \\
\hline 高庴系 & & 7 & 5 & \\
\hline 新デザイン系 & 32 & 29 & 28 & 31 \\
\hline 低居系 & (3) & $\overline{44}$ & W(158 & 41 \\
\hline 中層系 & 16 & 20 & 15 & 22 \\
\hline 合社(入) & 101 & 134 & 102 & 118 \\
\hline
\end{tabular}

○年踾・性別・居住者・職業の有無など

若者と年寄りを比べると、低層系を好む傾向は年寄りの 方がやや強いが、中層系については、若者は年寄りに比 へ、志向が強いことが分かった（表-11a）。

女性と男性を比べると、低層系を理想とする人は男性 に多いが、中層系は女性の方がより多い（表-11b）。

居住者と非居住者を比べると: 居住者の回答人数はか なり多い。中高層系や新デザイン系について、両者の割 合の差異があまり見られないが、非居住者のほうが低層 系の志向がやや高いことが分かった（表-11c）。

無職者と有職者を比べると、有職者は低層系の志向が やや高く、中高層系や新デザイン系については両者の認 識が泳同じである（表-11d）。

表-11 理想像と年柃 - 性別 - 居住者・職業の有無注9)

\begin{tabular}{|c|c|c|c|c|c|c|c|c|}
\hline \multirow{2}{*}{$\begin{array}{ll}\text { 理 想 像 } \\
\text { \% }\end{array}$} & \multicolumn{2}{|c|}{ 年歯 } & \multicolumn{2}{|c|}{ 性别 } & \multicolumn{2}{|c|}{ 居住者 } & \multicolumn{2}{|c|}{ 倳啋 } \\
\hline & 若者 & 年奇り & 男 & 女 & 定 & 否定 & 有 & 無 \\
\hline 高層系 & 6 & 4 & 4 & 6 & 6 & 4 & 4 & 6 \\
\hline 新デザイン系 & 30 & 29 & 28 & 30 & 30 & 28 & 30 & 29 \\
\hline 低崮系 & 42 & 57 & 558 & 45 & 47 & 51 & 512 & 47 \\
\hline 中層系 & 123 & 11 & 15 & 19 & 18 & 17 & 16 & 19 \\
\hline 合就(人) & 146 & 108 & 104 & 150 & 32 & 13 & 15 & 30 \\
\hline 区分 & & & 1 & & & & & \\
\hline
\end{tabular}

\section{6.まとめ一「原環境」像の存在に関する考察}

環境の原型（proto-environment）の存在について、住 宅の特徵によって人々に異なった反応があり、住棟形態 
別の原型という手がかりが得られた。しかし、これまで の原風景論における風景に共感するという精神的意味に ついては、住宅の物理的特徽のみの調查方法では、明ら かにすることが出来なかった。

この研究は、旧い住環境、低、中、高層住棟という常 識的な差異を明らかにしただけなので、取り立てて独創 的ではないと考えられる。しかし、ます居住体験では、 農山村や、近代化後の農山村、および都市住宅の3グ ループに及び、はっきりと住宅形式の近代化が裹付けら れると共に、過半が都市住宅体験者となっている。しか も、環境の理想像では、極端に低層系住宅が好まれ逆に 高層住棟が嫌われている点が、明らかにされている。こ の点からは、低層系環境こそが「ur-environment」であると いっても言い過ぎでないと考える。このように、予想さ れたことではあるが、志向の主な方向が明らかにされた ことが新しい点ではないかと考えられる。また、都市住 宅の居住体験と低層系の理想像という関連、都市体験の ない人々の高層系の理想像という、いわば、逆転した関 係も意味ある結論であった。

今後は、風景や環境への共感などの傾向や、より詳細 な住宅形式の理想諭、また地域差、人口特性差などにつ いての課題が考えられる。

\section{注：}

1)「沿道」とは，住棟を道路の西辺に配置する方式。

2)「椱合」は，住棟の配置は単一でなく，二つ以上の方式を合成し，出 来たものという。農村旧」とは, 古い日本の伝統的な農村をいう。 3）老/若とは, 40 代以上の人と 40 代以下の人の比率をいう。居住者/ 非居住者とは，調查対象地域の居住者と非居住者の比率をいう。

4) $\mathrm{O} \rightarrow 1, \mathrm{O} \rightarrow 2, \Delta \rightarrow 3, X \rightarrow 4$ と数值化した。

5) $\rightarrow 1, \mathrm{O} \rightarrow 2, \Delta \rightarrow 3, X \rightarrow 4, \times X \rightarrow 5$ と数值化した。

6）体験と理想の関係を見るためには，回答者の分類が必要である。ク ラスター分析のグルーブはイメージの分類であるので適さない。新し い回答のタイブは，呈示した㻴境の特徽の組み合わせから、タイブが舍 むイメージへの回答が少くとものと○をひとつ含む回答者から、その他 の回答者を区別してタイブ化した。例えば，村落系のタイブのどれか
ひとつのタイブに,○か○の回答があれば村落系回答者とし,他を非村 落系とした。

7) カイ自乘検定の事前処理として、居住体験と理想像の類型事例数 の少ないタイブをまとめ（有効回答のみ）、居住体験は、A、B、C及 びDの4タイプ、理想像は、a、b、c及びdの4タイブとした（下の表に 示す)。(4-1)(4-1)=9で、9次元のカイ自乗検定を行い、危険率 $5 \%$ で 有意差があると判定された。

居住体験と理想像のタイブの分類表

\begin{tabular}{|c|c|c|c|c|c|}
\hline 理想像 居住体蜸 & $\begin{array}{c}\text { A } \\
(\mathrm{I})\end{array}$ & $\begin{array}{c}\mathrm{B} \\
\text { (II) }\end{array}$ & $\begin{array}{c}\mathrm{C} \\
\text { (IV) }\end{array}$ & $\begin{array}{c}\mathrm{D} \\
(そ の \text { 他 })\end{array}$ & $\begin{array}{l}\text { 合㖕（人） } \\
\text { (8タイフ })\end{array}$ \\
\hline$a(1,2,3,4,6,9,10,11,12,14$ & 25 & 11 & 15 & 3 & 54 \\
\hline$b(13,15)$ & 30 & 16 & 8 & 7 & 61 \\
\hline$c(5,7,8)$ & 28 & 23 & 6 & 4 & 61 \\
\hline$d(16)$ & 17 & 10 & 5 & 2 & 34 \\
\hline 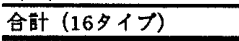 & 132 & 60 & 34 & 16 & 210 \\
\hline
\end{tabular}

8）農村から，近代化が序々に進み，大都市に変身する都市化システム である。

9）簡略化のため、比率の小数点以下は四捨五入して、示していな い。又、比率の差の检定によって、4\%迄は、危険率 $5 \%$ で差があると いう結果となった。そこで、有意差のある項目のみ網掛けをした。

参考文献:

1）扇田信：住居観の研究一住意識について一,日本建笨学会論文報告 集第68号,pp178-183.1961

2) 奥野健男：文学における原風景，集英社, pp39-56, 1972

3) 小山田善次郎：都市景観のイメージ調查一（I) 鹿児島市の場合一、日 本建築学会論文報告集第 212 号,pp59-65, 1973

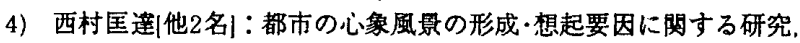
第27回日本都市計画学会学術研究論文集, pp721-726, 1992 /名古屋 市の心像風景の場所性について一都市の心象風景に関する研究・その 1一名古屋市中心市街地の心象風景の情緒的意味と方向性について一 都市の心象風景に関する研究・その2一, 日本建筑学会学術請演梗概集 (東北), pp155·158,1991

5）茂原朋子(他 2 名|：青年の “原風景”の特性と構造に関する研究，第 26回日本都市計画学会学術研究論文集, pp457-462, 1991

6) 延藤安弘：住志向に関わる原風景一ふるさとの思い出からみた住 居の鱽画. 1987·住生活研究会,ライスス夕价からみた住居・環境計画に関す る調查研究. 1987

7) 関根康正: 原風景試論,季刊人類学 13 巻 1 号, pp 164-193, 1982

8) 岩田慶治の原風景諭：参7同号, pp191

9）F・レンクーローマイス：都市は “ふるさと”か，鹿島出版社, pp46-70,1978 